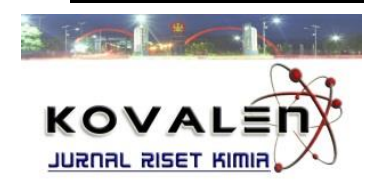

\title{
PENENTUAN WAKTU PARUH ENZIM AMILASE AMOBIL DARI KECAMBAH KACANG HIJAU (Phaseolus aureus) PADA PRODUKSI GLUKOSA DARI MALTODEKSTRIN
}

\section{[Determination of The Half-Life of Immobilized Enzyme From Mung Bean Sprouts (Phaseolus aureus) for Production of Glucose From Maltodextrin]}

\author{
Nurain Turah $^{1^{\star}}$, Syaiful Bahri ${ }^{1}$, Nurakhirawati ${ }^{1}$ \\ 1 Jurusan Kimia Fakultas MIPA, Universitas Tadulako \\ Jl. Soekarno Hatta Km.9, Kampus Bumi Tadulako Tondo Palu, Telp. 0451- 422611
}

Diterima 21 April 2017, Disetujui 20 Juni 2017

\begin{abstract}
The investigation about determination of the half life of the immobilized enzym from mung bean sprouts (Phaseolus aureus) for glucose production from maltodextrin has been done. The aim of the research are to determine the best ratio of mung bean sprouts to water for amylase enzyme isolation process, to determine the best alginat concentration for immobilization process, and to determinant the half life of immobilized enzyme in hydrolizyng the maltodextrin to become glucose. This research was designed using completely randomized design (CRD), with 2 factorial pattern (the ratio of the mung bean sprouts toward the water and alginat concentration). Each factor consist of 5 levels ( 1:1, $2: 1,3: 1,4: 1,5: 1(\mathrm{w} / \mathrm{v})$ and $2 \%, 2.5 \%, 3 \%, 3.5 \%$ and $4 \%$ respectively). The observed parameter was glucose content. The result showed that the best ratio of mung bean sprouts toward the water was $3: 1$, while the best alginate concentration for glucose production was $3 \%$. The obtained glucose content of those parameter were $3966.52 \mathrm{mg} / \mathrm{L}$ and $4686.54 \mathrm{mg} / \mathrm{L}$ respectively. The obtained immobilized enzyme half life was 444,34 minutes.
\end{abstract}

Keywords: mung been sprouts, alginate, amylase, maltodextrin, glucose.

\begin{abstract}
ABSTRAK
Telah dilakukan penelitian tentang penentuan waktu paruh enzim amobil dari kecambah kacang hijau (Phaseolus aureus) untuk produksi glukosa dari maltodekstrin. Penelitian ini bertujuan untuk mengetahui rasio kecambah kacang hijau : air terbaik untuk proses isolasi enzim amilase, dan konsentrasi terbaik alginat untuk proses amobilisasi serta menentukan waktu paruh enzim amobil dalam menghidrolisis maltodekstrin menjadi glukosa. Penelitian dirancang menggunakan Rancangan Acak Lengkap (RAL) yang terdiri atas 2 faktor yaitu rasio kecambah kacang hijau : air terdiri atas 5 taraf $(1: 1,2: 1,3: 1,4: 1$, dan $5: 1(\mathrm{~b} / \mathrm{v}))$ dan konsentrasi alginat terdiri dari 5 taraf $(2 \%, 2,5 \%, 3 \%, 3,5 \%$, dan $4 \%$ ) yang masing-masing dilakukan secara duplo. Parameter yang diamati adalah kadar glukosa. Hasil penelitian menunjukkan rasio kecambah kacang hijau : air terbaik untuk produksi amilase kasar yang digunakan dalam produksi glukosa dari maltodekstrin adalah 3:1 (b/v) dengan kadar glukosa $3966,52 \mathrm{mg} / \mathrm{L}$, konsentrasi alginat terbaik yang digunakan sebagai bahan pengamobil amilase kasar untuk produksi glukosa dari maltodekstrin adalah konsentrasi 3\% dengan kadar glukosa 4686,54 $\mathrm{mg} / \mathrm{L}$, dan waktu paruh enzim amobil yang diperoleh adalah 444,34 menit.
\end{abstract}

Kata Kunci : kecambah kacang hijau, alginat, amilase, maltodekstrin, glukosa. 


\section{LATAR BELAKANG}

Glukosa termasuk golongan monosakarida dengan gugus utama aldehid dan termasuk senyawa aldosa. Glukosa dapat diproduksi dengan cara proses hidrolisis pati baik menggunakan katalis asam maupun katalis enzim berupa enzim amilase. Penggunaan metode hidrolisis secara enzimatik lebih baik jika dibandingkan menggunakan asam, karena enzim bekerja secara spesifikasi sehingga produk yang dihasilkan sesuai dengan yang diinginkan. Selain itu, biaya pemurnian produk lebih mudah dan produk samping yang dihasilkan kecil (Winarno, 1995).

Produksi enzim dalam bentuk murni memerlukan biaya yang cukup tinggi, sehingga perlu dicarikan alternatif dengan memanfaatkan sumber daya alam dengan cara perkecambahan pada bahan yang banyak mengandung amilum. Kecambah kacang hijau adalah salah satu yang berpotensi sebagai sumber enzim aamilase (Suarni \& Patong, 2007). Penelitian Suarni dan Ubbe (2005), telah melakukan modifikasi pati jagung menggunakan enzim $\beta$-amilase yang berasal dari kecambah kacang hijau. Enzim $\beta$-amilase yang digunakan tidak dipisah dari kecambah.

Enzim umumnya larut baik dalam air sehingga enzim menjadi tidak ekonomis bila digunakan secara berulang. Langkah yang dapat dilakukan untuk mengatasi masalah tersebut adalah dengan cara membuat enzim amobil melalui proses imobilisasi enzim. Bahan yang umum digunakan sebagai pengamobil adalah alginate dan bahan lainnya.

Dewasa ini telah banyak ditemukan berbagai teknik amobilisasi enzim sehingga dapat menekan biaya produksi tanpa mengurangi aktivitas dari enzim tersebut. Khairunnisa dkk. (2013), telah melakukan penelitian tentang amobilisasi enzim $\alpha$-amilase ke dalam matriks bacto agar dengan penurunan aktivitas sebesar $44,83 \%$ pada pemakaian ketiga. Ratnaningsih (2004) telah melakukan penelitian tentang amobilisasi lipase pada matriks alginat, dan diperoleh konsentrasi terbaik dari alginat yang digunakan adalah sebesar $2 \%$. Berdasarkan penelitianpenelitian tersebut maka perlu adanya kajian tentang proses amobilisasi amilase kasar dengan menggunakan alginat sebagai carrier.

Efektifitas penggunaan enzim amobil dapat dilihat berdasarkan hasil hidrolisis enzim amobil tersebut terhadap substrat yang digunakan. Salah satu faktor yang dapat menjadi parameter kestabilan enzim amobil adalah waktu paruh.

Waktu paruh enzim didefinisikan sebagai waktu yang dibutuhakan oleh enzim untuk berinteraksi dengan substrat pada suhu tertentu yang menyebabkan penurunan aktivitas enzim hingga 50\% dari aktivitas semula (Chaplin dan Bucke, 1990). Dalam penelitian akan diuji aktivitas dan efektivitas penggunaan enzim amobil. Berapa kali enzim amobil ini dilakukan sehingga masa paruhnya dapat diketahui. 


\section{METODE PENELITIAN}

\section{Bahan dan Peralatan}

Bahan utama yang digunakan adalah maltodekstrin, glukosa, kecambah kacang hijau (2 hari), ammonium sulfat teknis, pereaksi DNS, alginat, $\mathrm{CaCl}_{2}, \mathrm{NaOH} 0,1 \mathrm{~N}$, dan akuades.

Alat yang diguanakan dalam penelitian ini yaitu neraca analitik, water bath, lumpang dan alu, spektrofotometer UV-Vis (Perkin Elmer Lambda 25), hot plate, kuvet, kain saring, aluminium foil, dan peralatan gelas penunjang lainnya.

\section{Prosedur Penelitian} Isolasi Amilase dari Kecambah Kacang
Hijau (Bahri et al., 2012)

Isolasi amilase dilakukan penambahan air dengan variasi kecambah kacang hijau : air 1:1, 1:2, 1:3, 1:4 dan 1:5 (v/b). Kecambah dihancurkan menggunakan blender, kemudian disaring dengan kain saring. Ekstrak kecambah sebanyak $100 \mathrm{~mL}$ ditambahkan ammonium sulfat sebanyak $55 \mathrm{~g}$ (tingkat kejenuhan $55 \%$ ). Campuran diaduk sampai homogen, kemudian didinginkan selama 24 jam sampai terbentuk koagulan. Koagulan dipisahkan dari larutan menggunakan Buchner. Endapan yang diperoleh disimpan dalam lemari pendingin selama 1 jam dan dimasukkan ke dalam pengering beku. Endapan yang diperoleh diuji aktivitasnya.

\section{Amobilisasi Amilase dengan Alginat (Bala, 2014)}

Membuat larutan alginat dengan konsentrasi $2 \%$; 2,5 \%; $3 \%$; 3,5 \% dan
4\% (b/v). Masing-masing ditambahkan ekstrak amilase kasar dengan perbandingan enzim dan alginat 1:10 (b/v), Campuran dimasukkan ke dalam alat injeksi, kemudian dibiarkan menetes ke dalam wadah yang berisi $\mathrm{CaCl}_{2} 1 \mathrm{M}$ dan terbentuk bola-bola kecil (gel). sambil diaduk. Gel yang terbentuk didiamkan 2 jam sampai gel mengeras. Gel enzim amilase amobil yang dihasilkan disimpan dalam lemari pendingin.

\section{Hidrolisis Maltodekstrin Menggunakan Amilase Amobil (Modifikasi Lugraha dan Dimas, 2008)}

Membuat larutan maltodekstrin $20 \%$ (b/v), dengan cara melarutkan maltodekstrin sebanyak $20 \mathrm{~g}$ ke dalam labu ukur $100 \mathrm{~mL}$. Larutan maltodekstrin sebanyak $30 \mathrm{~mL}$ dimasukkan ke dalam erlenmeyer dan ditambahkan enzim amobil sebanyak $10 \mathrm{~g}$ (perbandingan 1:3 (b/v)), selanjutnya ditambahkan buffer posfat $\mathrm{pH}$ 6 dan dipanaskan pada suhu $60^{\circ} \mathrm{C}$ selama 3 jam.

\section{Penetapan Kadar Glukosa dengan Metode DNS (Chafid dan Kusumawardani, 2010)}

Sebanyak $1 \mathrm{~mL}$ larutan gula hasil hidrolisis dimasukkan ke dalam tabung reaksi dan ditambahkan dengan $3 \mathrm{~mL}$ pereaksi DNS, selanjutnya dipanaskan pada penangas air mendidih selama 5 menit kemudian didinginkan pada suhu ruang. Larutan dipindahkan ke dalam kuvet, absorbansi diukur pada panjang gelombang maksimum 550 nm. Kadar glukosa ditentukan dengan menggunakan persamaan regresi kurva standar. 
Penentuan Waktu Paruh Amilase Amobil

Amilase amobil dengan aktivitas terbaik pada perlakuan sebelumnya digunakan secara berulang, kemudian ditentukan kadar glukosanya, dan selanjutnya ditentukan orde reaksi dari reaksi. Waktu paruh enzim amobil ditentukan berdasarkan nilai slope dari persamaan regresi linear yang diperoleh.

\section{HASIL DAN PEMBAHASAN}

\section{Ekstrak Amilase dari Kecambah Kacang Hijau}

Rendemen amilase kasar yang diperoleh dari proses ekstraksi menggunakan perbandingan kecambah kacang hijau dan air yaitu 1:1, 2:1, 3:1, 4:1, dan 5:1 (b/v) adalah berturut-turut adalah $1,16 \% ; 1,28 \% ; 1,50 \% ; 1,21 \%$ dan $1,02 \%$.

Ekstrak kasar enzim yang diperoleh diuji aktivitas amilasenya dalam menghidrolisis maltodekstrin menjadi glukosa dengan penambahan buffer posfat $\mathrm{pH}$ 6. Penambahan buffer posfat ini bertujuan untuk mempertahankan $\mathrm{pH}$ larutan dalam sistem. Menurut Soebijanto (1986), aktivitas enzim $\beta$-amilase bekerja efektif pada $\mathrm{pH}$ 5,0-6,0.

Enzim $\beta$-amilase bekerja secara eksoamilase yaitu memutus ikatan 1,4glikosidik dari ujung rantai maltodekstrin dalam proses sakarifikasi. Proses sakarifikasi merupakan proses hidrolisis maltodekstrin menjadi glukosa dengan mekanisme reaksi sebagai berikut :

$$
\begin{array}{lc}
\multicolumn{3}{c}{\beta \text {-amilase }} \\
\underset{\left(\mathrm{C}_{12} \mathrm{H}_{22} \mathrm{O}_{11}\right)_{n}+\mathrm{H}_{2} \mathrm{O} \longrightarrow}{\text { Dekstrin }} \quad \text { Air } & \left(\mathrm{C}_{6} \mathrm{H}_{12} \mathrm{O}_{6}\right) \\
\text { Glukosa }
\end{array}
$$

Gambar 1. Reaksi hidrolisis menggunakan $\beta$ amilase (Perry et al., 1999)

Rasio antara kecambah kacang hijau dan air berkorelasi positif terhadap aktivitas enzim yang dihasilkan (Gambar 2). Aktivitas amilase tertinggi dapat dilihat berdasarkan konsentrasi glukosa yang dihasilkan dalam proses hidrolisis. Konsentrasi glukosa tertinggi yang dihasilkan adalah $3.984,62 \mathrm{mg} / \mathrm{L}$, dengan berat glukosa 0,1426 $\mathrm{g}$ dan rendemen glukosa sebesar $1,426 \%$ pada perbandingan 1:3 (air : kecambah kacang hijau).

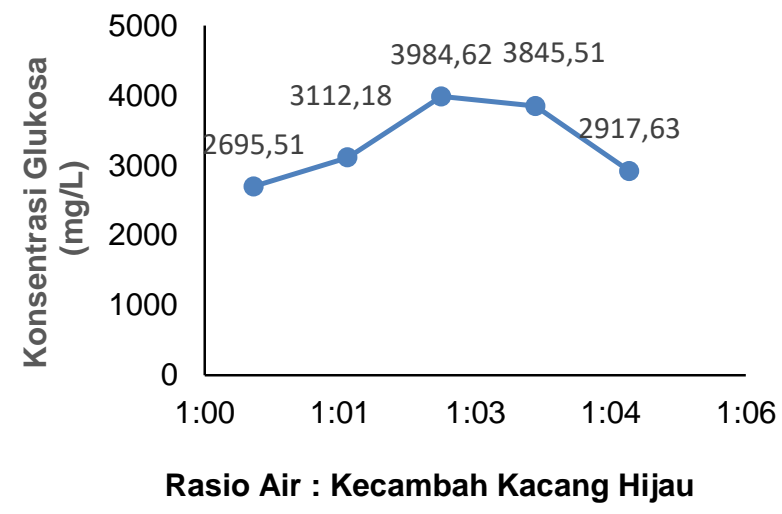

Gambar 2. Grafik pengaruh rasio air dan kecambah kacang hijau terhadap konsentrasi glukosa hasil hidrolisis.

Glukosa yang dihasilkan diukur kadarnya dengan metode DNS yaitu menggunakan pereaksi DNS (asam 3,5dinitrosalisilat). Pereaksi ini direduksi oleh gula pereduksi menghasilkan asam 3amino-5-nitrosalisilat (Gambar 3). Hal tersebut dapat dilihat berdasarkan 
perubahan warna yang terjadi dari warna kuning menjadi merah bata setelah pemanasan. Selanjutnya sampel diukur menggunakan spektrofotometer UV-Vis pada panjang gelombang $550 \mathrm{~nm}$. Banyaknya DNS yang tereduksi berbanding lurus dengan banyaknya kadar glukosa yang diperoleh dalam sampel.

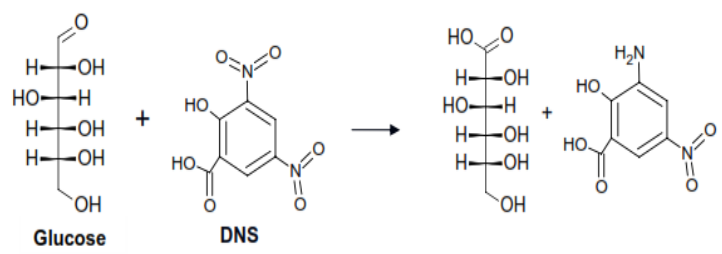

Gambar 3. Reaksi Glukosa dengan Asam 3,5Dinitrosalisilat (Miloski et al., 2008).

Konsentrasi glukosa yang dihasilkan mengalami peningkatan dari perbandingan $1: 1$ sampai $1: 3$, kemudian mengalami penurunan pada perbandingan 1:4 dan 1:5 (Gambar 2). Hal ini menunjukkan bahwa ada pengaruh jumlah kecambah kacang hijau terhadap aktivitas enzim amilase yang dihasilkan. Hal tersebut kemungkinan disebabkan oleh adanya pengaruh dari tingkat kejenuhan ammonium sulfat yang digunakan sebagai pengendap molekulmolekul protein dari kecambah kacang hijau yang digunakan sebagai sumber amilase. Semakin banyak kecambah yang digunakan maka molekul protein yang diendapkan semakin banyak, namun setelah mencapai titik tertentu maka molekul protein yang terendapkan semakin berkurang seiring bertambahnya jumlah kecambah yang digunakan, sebab kecambah juga mengandung cukup banyak kadar air. Kadar air yang terlalu banyak mempengaruhi tingkat kejenuhan dari ammonium sulfat yang digunakan, sehingga proses salting out tidak terjadi secara sempurna (Bahri et al., 2012).

\section{Amilase Terimobilisasi Alginat}

Untuk mengetahui pengaruh konsentrasi alginat terhadap aktivitas enzim amobil dalam menghasilkan kadar glukosa terbaik diterapkan variasi konsentrasi alginat. Enzim yang digunakan dalam perlakuan ini adalah enzim yang telah diisolasi dari kecambah kacang hijau pada perlakuan sebelumnya. Sedangkan perbandingan enzim dan alginat yang diterapkan adalah 1:10 (Bala, 2012).

Konsentrasi alginat berkorelasi positif terhadap aktivitas enzim amobil yang dihasilkan (Gambar 4). Aktivitas amilase amobil tertinggi dapat dilihat berdasarkan konsentrasi glukosa yang dihasilkan dalam proses hidrolisis. Konsentrasi tertinggi yang dihasilkan adalah 4.686,54 mg/L, dengan berat glukosa 0,199 $\mathrm{g}$ dan rendemen glukosa sebesar $1,922 \%$ pada konsentrasi alginat $3 \%$.

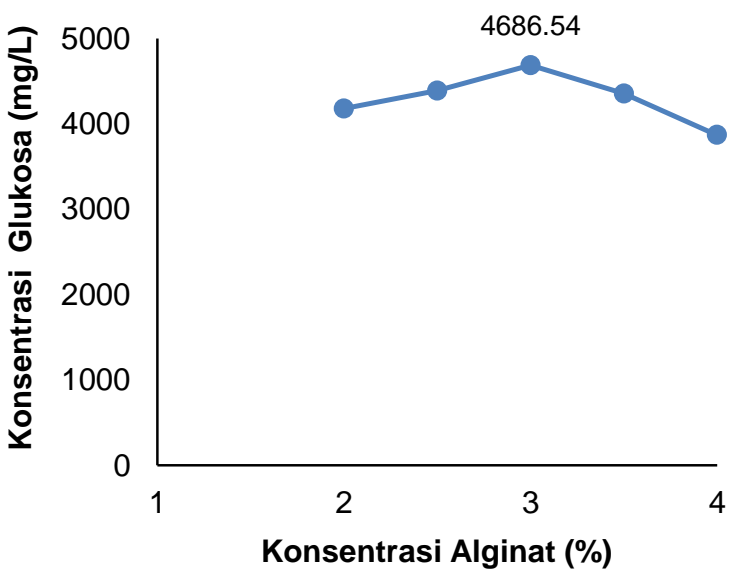

Gambar 4. Grafik pengaruh konsentrasi alginat terhadap konsentrasi glukosa hasil hidrolisis. 
Konsentrasi alginat yang digunakan sebagai bahan pengamobil berpengaruh terhadap aktivitas enzim amilase amobil dalam menghidrolisis maltodekstrin menjadi glukosa, hal tersebut dapat dilihat berdasarkan kadar glukosa yang dihasilkan (Gambar 4). Hal tersebut disebabkan karena semakin tinggi konsentrasi alginat maka kekuatan gel yang trebentuk semakin kuat. Semakin kuat gel yang terbentuk maka semakin sulit terjadinya kontak enzim dengan substrat yang ada, sebab kekuatan gel mempengaruhi distribusi substrat ke dalam pori-pori gel alginate (Ratnaningsih, 2004).

Sehingga pada konsentrasi alginat yang tinggi kadar glukosa yang dihasilkan semakin rendah. Smitth (1990) menyatakan bahwa amobilisasi enzim dengan metode penjebakan akan menyebabkan penghambatan kerja enzim, sebab bahan pengamobil yang digunakan dalam metode penjebakan cenderung memiliki berat molekul yang tinggi sehingga mengganggu interaksi antara enzim dan substrat. Menurut Ratnaningsih (2004), semakin tinggi konsentrasi alginat yang digunakan dalam proses amobilisasi maka ukuran pori-pori dari manik-manik yang dihasilkan (enzim amobil) semakin kecil sehingga akan menghambat difusi substrat ke dalam manik-manik Ca-alginat.

\section{Waktu Paruh Enzim Amilase Amobil dari Kecambah Kacang Hijau}

Waktu paruh enzim amobil yang dihasilkan ditentukan dengan melakukan penggunaan ulang enzim amobil tersebut dengan interval waktu 30 menit pada tiap pengulangan.

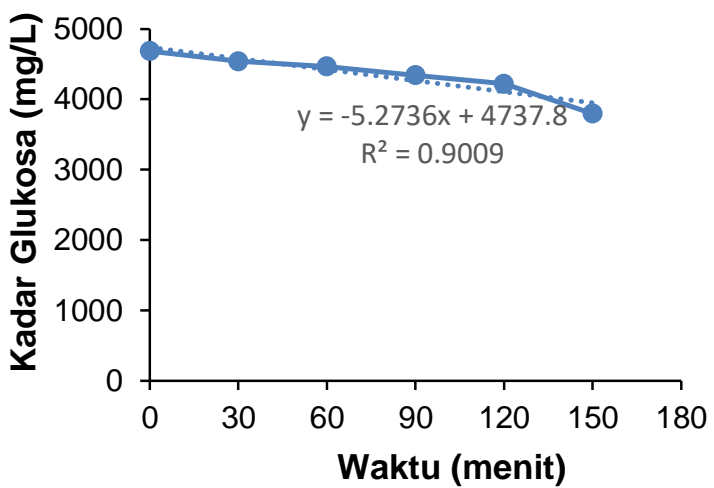

Gambar 5. Grafik hubungan kadar glukosa terhadap waktu penggunaan ulang enzim amobil pada orde nol.

Semakin banyak pengunaan enzim amobil secara berulang maka kadar glukosa yang dihasilkan semakin rendah (Gambar 5). Hal ini disebabkan karena terjadi penurunan aktivitas enzim amobil seiring dengan adanya penggunaan berulang. Penurunan aktivitas ini terjadi akibat pelepasan enzim dari polimer (bahan pengamobil) yang digunakan selama pemakaian, sebab tidak adanya pengikatan secara kimia antara enzim dan gel alginat yang digunakan, sehingga enzim mudah lepas dan keluar bersama produk yang terbentuk. Semakin banyak penggunaan berulang maka jumlah enzim dalam gel semakin berkurang (Su'i dkk., 2007).

Berdasarkan persamaan yang diperoleh (Gambar 5), dapat ditentukan waktu paruh enzim amobil dari kecambah kacang hijau yang diperoleh yaitu 444,34 menit. Menurut Yandri dan Wulandari (2009), waktu paruh enzim a-amilase setelah penambahan sorbitol $1 \mathrm{M}$ yaitu sebesar 48,80 menit. 


\section{KESIMPULAN}

Rasio terbaik antara kecambah kacang hijau dan air untuk produksi amilase kasar yang digunakan dalam produksi glukosa dari maltodekstrin adalah 3:1 (b/v) dengan rendemen glukosa sebesar $1,426 \%$, sedangkan konsentrasi terbaik alginat yang digunakan sebagai bahan pengamobil amilase kasar dari kecambah kacang hijau untuk produksi glukosa dari maltodekstrin adalah $3 \%$ dengan rendemen glukosa sebesar 1,922 $\%$, dan waktu paruh dari enzim amilase amobil adalah 444,34 menit.

\section{UCAPAN TERIMAKASIH}

Secara khusus $r$ peneliti
menyampaikan ucapan terima kasih
kepada Laboran Jurusan Kimia dan
Himpunan Mahasiswa Kimia (HIMAKIM)
FMIPA UNTAD.

\section{DAFTAR PUSTAKA}

Bala, S. 2014. Kajian Imobilisasi Enzim Invertase untuk Produksi Gula Invert dari Nira Kelapa. Skripsi. Palu: Program Studi Kimia. Universitas Tadulako.

Chafid A., Kusumawardani G. 2010. Modifikasi Tepung Sagu Menjadi Maltodekstrin Menggunakan Enzim a-amilase. Skripsi. Semarang: Universitas Diponegoro.

Chaplin M.F. dan Bucke C. 1990. Enzyme Technology. Cambridge: Cambridge University Press.

Bahri, S., Mirzan, M., \& Hasan, M. (2013). Karakterisasi Enzim Amilase Dari Kecambah Biji Jagung Ketan (Zea mays ceratina L.). Natural Science: Journal of Science and Technology, 1(1).
Khairunnisa, Wuryanti, Taslimah. 2013. Isolasi, Karakterisasi dan Amobilisasi a-amilase dari Aspergillus FNCC 6018. Chem Info. 1 (1) : 141-149.

Lugraha A., Dimas Damar A. 2008. Pemanfaatan Sukun (Artocarpus altiris) sebagai Bahan Baku Pembuatan Gula Rendah Kalori Secara Enzimatis Menggunakan Enzim $\beta$-amilase dari Kecambah Kacang Hijau. Proceding Seminar Hasil Penelitian. Semarang: Universitas Diponegoro.

Miloski K., Wallace K., Fenger A., Schneider E. 2008. Comparison of Biochemical and Chemical Digestion and Detection Methods for Carbohydrates. New York: Department of Chemistry State University of New York-Oswego.

Perry, Robert H., Don W. Green, James O. Maloney. 1999. Perry's Chemical Engineers. Handbook. USA: McGraw Hill Company Inc.

Ratnaningsih N. 2004. Pengaruh Variasi Konsentrasi Alginat dan Konsentrasi Lipase Terhadap Aktivitas Hidrolisis dan Aktivitas Spesifik Lipase Amobil Pada Proses Amobilisasi Lipase dari Rhizopus Delemar. Jurnal Penelitian Saintek. 9 (1) : 31-49.

Smitth J. E. 1990. Biotechnology. Penerjemah Hartono, A. Buku Kedokteran Indonesia. Jakarta: Gramedia.

Soebijanto. 1986. HFS dan Industri Ubi Kayu Lainnya. Jakarta: Gramedia.

Suarni dan U. Ubbe. 2005. Perbaikan Kandungan Nutrisi dan Sifat Fisikokimia Tepung Sorgum dengan Enzimatis ( $\beta$-amilase) dari Kecambah Kacang Hijau. Proceding Seminar Nasional Kimia. Makassar: Universitas Hasanuddin.

Suarni, Patong R. 2007. Potensi Kecambah Kacang Hijau sebagai Sumber Enzim a-Amilase. Indo J. Chem. 7 (3) : 332-336.

Su'i M., Yunianta, Harijono, Aulani'am. 2007. Perubahan Aktivitas Enzim 
Amobil Lipase dari Kentos Kelapa. Agritech Universitas Brawijaya.

Malang. 30 (3) : 81-85.

Winarno, F.G. 1995. Kimia Pangan dan Gizi. Jakarta: Gramedia Pustaka Utama.

Yandri A.S., Pretty Wulandari. 2009. Pengaruh penambahan sorbitol terhadap stabilitas termalEnzim $\alpha$ amilase dari Rhizopus oryzae. Jurnal Sains MIPA. 15 (2) : 111 - 118. 